nghiên cứu này, tác giả sử dụng phương pháp nuôi cấy để đánh giá số lượng khuẩn lạc lactobacilli. Phương pháp đánh giá trên nhuộm gram hệ vi sinh vật cũng được Yan và cs (2009) sử dụng trên 150 phụ nữ tại Bắc Kinh [9]. Kết quả cho thây, phần lớn bệnh nhân viêm âm đạo không đặc hiệu được phân độ lactobacilli độ III $(91 \%, 42 / 46$ trường hợp) và độ II $(9 \%, 4 / 46$ trường hợp); trong khi đó, nhóm phụ nữ khỏe mạnh có $64 \%$ độ I (67/104 trường hợp) và $36 \%$ độ II (37/104 trường hợp). Kết quả này tương đồng với nghiên cứu của chúng tôi được trình bày ở bảng 3.9 , độ II chiếm $76,9 \%$ và độ III chiếm $23,1 \%$ và không có trường hợp nào độ $I$. Như vậy, trong viêm âm đạo không đặc hiệu có sự suy giảm về mặt số lượng lactobacilli cũng như các loài lactobacilli.

\section{KẾT LUẬN}

Viêm âm đạo không đặc hiệu có xu hướng gặp ở đối tượng trẻ tuổi từ 18-30, có tỉ lệ gặp cao hơn ở nhóm có tiền sử bênh liên quan nao hút thai, sảy thai. Đa số bệnh nhân có biểu hiện triệu chứng trong đó thường gặp là mùi khí hư, ngứa rát âm hộ, giao hợp đau. Xét nghiệm cho thấy sự rối loạn của hệ vi sinh vật tại âm đạo, số lượng lactobacilli suy giảm và gia tăng các loài vi khuẩn gram âm, câu khuẩn gram dương khác.

\section{TÀl LIÊU THAM KHẢO}

1. Javed A., Parvaiz F., Manzoor S. (2019). Bacterial vaginosis: An insight into the prevalence, alternative treatments regimen and it's associated resistance patterns. Microb Pathog, 127, 21-30.
2. Kamga Y.M., Ngunde J.P., Akoachere J.K.T. (2019). Prevalence of bacterial vaginosis and associated risk factors in pregnant women receiving antenatal care at the Kumba Health District (KHD), Cameroon. BMC Pregnancy Childbirth, 19(1), 1-8.

3. Lê Hiếu Hanh, Lê Thái Vân Thanh, Văn Thế Trung (2019). Viêm âm đạo và các yễu tố liên quan ở bệnh nhân nữ tại Bệnh viện Da liễu TP. Hồ Chí Minh. Y học TP. Hồ Chí Minh, 23(1), 38-44.

4. Đinh Thị Huyền Ngọc (2013), Nghiên cứu hiệu quả điều tri của Gynoflor trong viêm âm đao không đặc hiệu tại Bệnh viện Phụ Sản Trung Ương, Luận vẳn Thạc sỹ y học, Đại học Y Hà Nội.

5. Faisal M.M., Abdel-Gawad M.M., Fahmy R.A. et al (2019). Change in Vaginal Flora as Indicated by Pap Smear (Schröder's Classification) in Women Using Levonorgestrel-Releasing Intrauterine System "Mirena"-Prospective Cohort Study. Open Journal of Obstetrics and Gynecology, 9(5), 631-642.

6. Ranjit E., Raghubanshi B.R., Maskey S. et al (2018). Prevalence of Bacterial Vaginosis and Its Association with Risk Factors among Nonpregnant Women: A Hospital Based Study. Int J Microbiol, 2018, 1-9.

7. Tamrakar R., Yamada T., Furuta I. et al (2007). Association between Lactobacillus species and bacterial vaginosis-related bacteria and bacterial vaginosis scores in pregnant Japanese women. BMC Infectious Diseases, 7(1), 128.

8. Chooruk A., Utto P., Teanpaisan $R$. et al (2013). Prevalence of lactobacilli in normal women and women with bacterial vaginosis. J Med Assoc Thai, 96(5), 519-522.

9. Yan D.H., Lü Z., Su J.R. (2009). Comparison of main lactobacillus species between healthy women and women with bacterial vaginosis. Chin Med J (Engl), 122(22), 2748-2751.

\title{
ĐÁNH GIÁ KẾT QUẢ ĐIÎ̀U TRỊ HộI CHỨNG THÂ̂N HƯ TIÊN PHÁT Ở TRẺ EM TẠI THÁI NGUYÊN
}

\section{TÓM TẮT}

Mục tiêu: Đánh giá kết quả điều trị hội chứng thân hư tiên phát ở trẻ em tai Thái Nguyên. Đối tượng: 30 bệnh nhi được chẩn đoán Hội chứng thận hư tiêp phát vào điều trị tại Bênh viện Trung Ương Thái Nguyên và Bệnh viện $A$ Thái Nguyên từ tháng $01 / 2019$ đến tháng 06/2021. Phương pháp nghiên cứu: Nghiên cứu mô tả cắt ngang. Kết quả: Nam mắc bệnh nhiều hơn nữ với tỷ lệ 4/1 (có 24 nam và 6

*Trường Đại hơ Y Dước - ĐH Thái Nguyên

Chịu trách nhiệm chính: Trương Thị Hồng Minh

Email: hongminhbsdk.dhyd@gmail.com

Ngày nhận bài: 19.8.2021

Ngày phản biên khoa hoc: 18.10.2021

Ngày duyệt bài: 29.10.2021

\section{Trương Thị Hồng Minh*, Nguyễn Văn Sơn*}

nữ). Tuổi trung bình mắc bệnh là 6,1 tuổi; nhóm tuổi 5-10 tuổi chiếm $63,3 \%$. Các bệnh nhi trong nghiên cứu có tỷ lệ phù $100 \%$, tăng huyết áp (40\%), thiểu niệu $(26,7 \%)$, protein niêuu 24 giờ trung bình 163,26 $\mathrm{mg} / \mathrm{kg} / 24 \mathrm{~h}$, albumin máu giảm nặng (trung bình 17,42 $\mathrm{g} / \mathrm{l}$ ), cholesterol tăng cao (trung bình $9,76 \mathrm{mmol} / \mathrm{l}$ ). Đáp ứng điều trị với corticosteroid là $76,7 \%$ với thới gian đáp ứng trung bình là 11,73 ngày. Tỷ lệ tái phát sau 3 tháng điêu trị là $36,67 \%$, trong đó chủ yếu là bệnh nhân thể kết hợp (87,5\%). Kết luân: Bệnh nhi mắc hội chứng thận hư tiên phát gặp phần lớn ở trẻ nam, chủ yếu lứa tuổi học đường, triệu chứng chủ yếu là phù, giảm năng albumin máu và protein niêuu tăng cao. Bệnh đáp ứng tốt với thuốc corticosteroid. Tỷ lệ bênh nhân tái phát chủ yếu ở nhóm hôi chứng thân hư tiên phát kết hợp. Tứ khóa: Trẻ em, hội chứng thận hư tiên phát, điêu trị 


\section{SUMMARY}

ASSESSING THE OUTCOME TREATMENT OF THE IDIOPATHIC NEPHROTIC SYNDROME

Objective: To assess the outcome of idiopathic nephrotic syndrome at Thai Nguyen. Subject: 30 children with idiopathic nephrotic syndrome were diagnosed and treated at Thai Nguyen national hospital and A hospital from 01/ 2019 to 03/ 2021. Methods: Descriptive cross-sectional study. Results: Males got involved in idiopathic nephrotic syndrome more than females with the ratio male to female of 4/1 (24 male and 6 female). The mean age at was 6.1 years old, group with patients from 5-10 years old were $63,3 \%$. The patients in study with signal edema $100 \%$, hypertension $40 \%$, oligulia $26,7 \%$, the mean of proteinuria $24 \mathrm{~h}$ was $163,26 \mathrm{mg} / \mathrm{kg} / 24 \mathrm{~h}$, severe hypoalbuminemia (average was 17,42 $\mathrm{g} / \mathrm{l}$ ), hypercholestrerolemia (average was $9,76 \mathrm{mmol} / \mathrm{l}$ ). The ratio patients response with corticosteroid was $76,7 \%$ and the mean time response with one was 11,73 days. Recurrence rate after 3 months of treatment was $36.67 \%$, of which mainly patients with combination type $(87,5 \%)$. Conclusion: The idiopathic nephrotic syndrome usually occurred in male, school age,the main symptoms were edema, severe hypoalbuminemia and hyperproteinuria. Chidren with idiopathic nephrotic syndrome responsed well to corticosteroid. The number of patients with relapse is mainly patients with combination type nephrotic syndrome.

Keyswords: Children, idiopathic nephrotic syndrome, treatment.

\section{I. ĐĂT VẤN ĐỀ}

Hội chứng thận hư là bệnh cầu thận mạn tính thường gặp nhất ở trẻ em, trong đó hội chứng thận hư tiên phát hay gặp nhất, chiếm khoảng 90\% bệnh nhân bị Hội chứng thận hư. Trước khi có corticosteroid, phần lớn bệnh nhân hội chứng thận hư sẽ chết trong 5 năm đầu do các biến chứng nhiễm khuẩn, suy thận, tắc mạch [2]. Từ năm 1955, corticosteroid bắt đầu sử dụng ngày càng rộng rãi, tiếp theo là các thuốc ức chế miễn dịch như cyclosporin, mycophenolat, mofetil, cyclophosphamide... diễn biến của bệnh đã thay đồi rất nhiều và tiên lượng tốt hơn với tỷ lệ chữa khỏi tới $90 \%$ và tỷ lệ tử vong trẻ bị Hội chứng thận hư còn $3 \%$. Tuy nhiên vẫn còn những trường hợp đáp ứng kém với điều trị và kháng lại corticosteroid. Theo P. Niaudet có $10 \%$ trẻ bị Hội chứng thận hư tiên phát kháng corticosteroid, ở Việt Nam theo Nguyễn Ngọc Sáng tỉ lệ này là 12,4\% [2]. Trong quá trình điều trị hội chứng thận hư tiên phát gặp rất nhiều tác dụng phụ của thuốc điều trị, theo Đoàn Thị Thẳm biến chứng bộ mặt Cushing và viêm dạ dày cấp xuất hiện ở tháng đầu tiên khi điêu trị bằng corticosteroid với tỷ lệ $>50 \%$, nên việc điều trị hội chứng thận hư vẫn là một thách thức với các bác sĩ nhi khoa. Chính vì vậy, chúng tôi thực hiện đề tài này nhằm mục tiêu: Đánh giá kêt quả điều trị hội chứng thận hư tiên phát ở trẻ em tại Thái Nguyên.

\section{II. ĐỐl TƯỢNG VÀ PHƯƠNG PHÁP NGHIÊN CỨU}

2.1. Đối tượng nghiên cứu. Bệnh nhi được chẩn đoán Hội chứng thận hư tiên phát vào điểu trị tại Bệnh viện Trung Ương Thái Nguyên và Bệnh viện $A$ Thái Nguyên từ tháng 01/2019 đến tháng $03 / 2021$.

\subsection{Tiêu chuẩn chọn bệnh nhân \\ Tiêu chuẩn lựa chọn}

- Bệnh nhi dưới 16 tuổi, nhập viện với chẩn đoán Hội chứng thận hư tiên phát. Bệnh nhân được chẩn đoán xác định là HCTHTP và điều trị theo "Hướng dẫn chẩn đoán và điều trị một số bệnh thường gặp ở trẻ em" của Bộ y tế ban hành kèm theo quyết định số 3312/QĐ-BYT ngày $07 / 08 / 2015$ về HCTHTP ở trẻ em: phù; protein/creatinine niệu $>0,2 \mathrm{~g} / \mathrm{mmol}$, hoặc > $40 \mathrm{mg} / \mathrm{m}^{2} / \mathrm{h}$ hoặc $50 \mathrm{mg} / \mathrm{kg} / 24$ giờ; albumin máu $<25 \mathrm{~g} / \mathrm{l}$, protein máu $<56 \mathrm{~g} / \mathrm{l}$, cholesterol máu tăng > 5,2 mmol/l [1].

- Gia đình bệnh nhân đồng ý tham gia nghiên cứu.

- Sử dụng phác đồ điều trị hội chứng thận hư tiên phát của Bộ Y tế năm 2015 [1]

\section{Tiêu chuân loại trừ}

Loại trừ HCTH thứ phát, bẩm sinh, tuổi khởi phát bệnh trước 3 tháng tuổi và do các nguyên nhân khác như: Lupus ban đỏ, hội chứng Scholein-Henoch ...

\subsection{Phương pháp nghiên cứu}

- Thiết kế nghiên cứu: Nghiên cứu mô tả

- Chọn mẫu nghiên cứu: Chọn mẫu thuận tiện, tất cả các bệnh nhân đủ tiêu chuẩn lựa chọn được đưa vào nghiên cứu.

\subsection{Các biến số}

- Lâm sàng: Tuổi nhập viện, giới tính, địa dư, phù, huyết áp, số lượng nước tiếu.

- Cận lâm sàng: Protein máu, albumin máu, protein niệu/kg/24 giờ.

- Thời gian điều trị: Được tính từ ngày bệnh nhân được sử dụng corticosteroid đến khi protein niệu trở về bình thường (tính theo ngày), bệnh nhân được điều trị theo phác đồ của Bộ Y tế năm 2015 [1]. Trường hợp đáp ứng tốt là thời gian điều trị dưới 14 ngày, đáp ứng chậm là từ sau 14 ngày.

2.5. Thu thập số liệu: Số liệu nghiên cứu được thu thập vào mấu bệnh án nghiên cứu ở các thời điểm bệnh nhân lúc bệnh nhân vào viện, sau 1 tháng và sau 3 tháng điều trị.

2.6. Xử lý số liệu: Sử dụng dụng phần mềm 
SPSS 25.0 để nhập và xử lý số liệu.

2.7. Đạo đức nghiên cứu: Đề tài được thông qua bởi Hội đồng $Y$ sinh học trường Đại học Y dược Thái Nguyên

\section{KẾT QUẢ NGHIÊN CỨU}

3.1. Đặc điểm chung của nhóm bệnh nhân nghiên cứu

Bảng 1: Đặc điểm chung của đôi tượng nghiên cứu

\begin{tabular}{|c|c|c|c|}
\hline \multicolumn{2}{|c|}{ Đă̆c điểm } & $\begin{array}{c}\text { Số } \\
\text { lượng }\end{array}$ & $\begin{array}{c}\text { Tỷ lệ } \\
\text { (\%) }\end{array}$ \\
\hline \multirow{2}{*}{ Giới } & Nam & 24 & 80 \\
\cline { 2 - 4 } & Nữ & 6 & 20 \\
\hline \multirow{2}{*}{ Địa dư } & Thành phố & 6 & 20 \\
\cline { 2 - 4 } & Nông thôn & 24 & 80 \\
\hline
\end{tabular}

\begin{tabular}{|c|c|c|c|}
\hline $\begin{array}{c}\text { Thể lâm } \\
\text { sàng }\end{array}$ & Đơn thuần & 22 & 73,3 \\
\cline { 2 - 4 } & Kết hợp & 8 & 26,7 \\
\hline \multirow{4}{*}{ Tuổi } & $<5$ & 6 & 20 \\
\cline { 2 - 4 } & $5-10$ & 19 & 63,3 \\
\cline { 2 - 4 } & $>10$ & 5 & 16,7 \\
\cline { 2 - 4 } & Trung bình & \multicolumn{2}{|c|}{$6,1 \pm 2,26$} \\
\cline { 2 - 4 } & Tuối nhỏ nhất & \multicolumn{2}{|c|}{3} \\
\cline { 2 - 4 } & Tuối lớn nhất & \multicolumn{2}{|c|}{11} \\
\hline
\end{tabular}

Nhân xét: Bênh găp ở trẻ nam nhiều hơn trẻ nữ với tỷ lệ nam/nữ = 4/1, chủ yếu bệnh nhi sinh sống ở vùng nông thôn $(80 \%)$, nhóm tuổi mắc bệnh nhiêu nhất từ $5-10$ tuổi $(63,3 \%)$, tiếp đến là nhóm tuổi dưới 5 tuổi $(20 \%)$ và thấp nhất là trên 10 tuổi. Thể đơn thuần là thể thường gặp trên lâm sàng.

\subsection{Kết quả điêuu trị}

Bảng 2: Thay đổi các triệu chứng lâm sàng sau điều trị

\begin{tabular}{|c|c|c|c|c|c|c|c|}
\hline \multicolumn{2}{|c|}{ Thời điếm } & \multicolumn{2}{|c|}{ Lúc vào viện } & \multicolumn{2}{|c|}{ Sau 1 tháng } & \multicolumn{2}{|c|}{ Sau 3 tháng } \\
\hline \multicolumn{2}{|c|}{ Triệu chứng } & Số lượng & Tỷ lệ (\%) & Số lượng & Tỷ lệ (\%) & Số lượng & Tỷ lệ (\%) \\
\hline \multirow{2}{*}{ Phù } & Có & 30 & 100 & 0 & 0 & 11 & 36.7 \\
\hline & Không & 0 & 0 & 30 & 100 & 19 & 63.3 \\
\hline \multirow{2}{*}{ Huyết áp } & Tăng & 12 & 40 & 6 & 20 & 4 & 13,3 \\
\hline & Bình thường & 18 & 60 & 24 & 80 & 26 & 86,7 \\
\hline \multirow{3}{*}{$\begin{array}{l}\text { Nước } \\
\text { tiểu }\end{array}$} & Vô niệu & 3 & 10 & 0 & 0 & 0 & 0 \\
\hline & Thiếu niệu & 8 & 26,7 & 0 & 0 & 4 & 13,3 \\
\hline & Bình thường & 19 & 63,3 & 30 & 100 & 26 & 86,7 \\
\hline
\end{tabular}

Nhận xét: Lúc nhập viện tất cả bệnh nhân đều có phù, $40 \%$ bệnh nhân có tăng huyết áp, $10 \%$ vô niệu, $26,7 \%$ thiểu niệu. Sau 1 tháng điều trị: các bệnh nhân đều hết phù, số lượng nước tiểu trở về bình thường, tỉ lệ tăng huyết áp giảm còn $20 \%$. Sau 3 tháng điều trị phù xuất hiện trở lại ở 36,7\% số bênh nhân, tăng huyết áp giảm xuống $13,3 \%$ và thiểu niệu $13,3 \%$.

\begin{tabular}{|c|c|c|c|c|}
\hline Xét nghiệm & Lúc vào viện & Sau 1 tháng & Sau 3 tháng & $\mathbf{p}$ \\
\hline $\begin{array}{l}\text { Protein niều } \\
\text { (mg/kg/24h) }\end{array}$ & $163,26 \pm 88,77$ & $35,38 \pm 21,26$ & $4,58 \pm 6,76$ & $\begin{array}{l}\mathrm{P}_{1,3}<0,05 \\
\mathrm{P}_{2,3}<0,05\end{array}$ \\
\hline Protein máu & $45,86 \pm 3,37$ & $58,56 \pm 5,81$ & $61,42 \pm 9,79$ & $\begin{array}{l}\mathrm{P}_{1,3}<0,05 \\
\mathrm{p}_{2,3}<0,05\end{array}$ \\
\hline Albumin máu & $17,42 \pm 2,86$ & $30,8 \pm 4,82$ & $40,27 \pm 12,21$ & $\begin{array}{l}\mathrm{P}_{1,3}<0,05 \\
\mathrm{p}_{2,3}<0,05\end{array}$ \\
\hline Cholesterol máu & $9,76 \pm 2,29$ & $7,71 \pm 1,69$ & $5,7 \pm 1,83$ & $\begin{array}{l}\mathrm{P}_{1,3}<0,05 \\
\mathrm{P}_{2,3}<0,05\end{array}$ \\
\hline
\end{tabular}

Nhân xét: Sau 3 tháng điều trị bênh nhi có nồng độ protein máu, albumin máu tăng cao hơn và nồng độ proetein niệu, cholesterol máu thấp hơn so với lúc trước điều trị, sau 1 tháng. Sự khác biệt có ý nghĩa thống kê với $\mathrm{p}<0,05$.

\begin{tabular}{|c|c|c|}
\hline $\begin{array}{l}\text { Thể lâm } \\
\text { sàng }\end{array}$ & $\begin{array}{c}\text { Thời gian đîêu } \\
\text { trị (ngày) }\end{array}$ & $\mathbf{p}$ \\
\hline Đơn thuân & $10,36 \pm 3,1$ & $<0,05$ \\
\hline Kết hợp & $15,5 \pm 68,22$ & $(p=0,017)$ \\
\hline Tống & \multicolumn{2}{|c|}{$11,73 \pm 5,35$} \\
\hline
\end{tabular}

Nhận xét: Thời gian điều trị trung bình của thể lâm sàng kết hợp (15,5 ngày) lâu hơn so với thể đơn thuần (10,36 ngày).

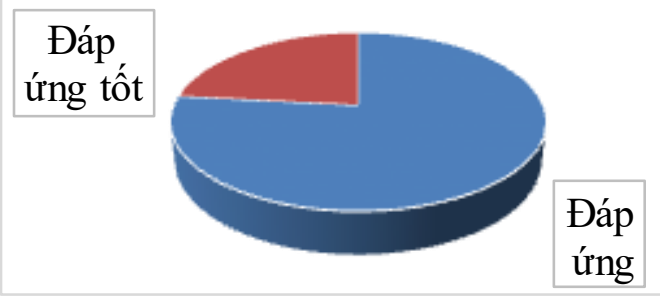

Biểu đồ 1: Phân bố bệnh nhân HCTHTP theo đáp ứng với corticoid 
Nhận xét: Đáp ứng tốt với corticoid chiếm $76,7 \%$ các trường hợp với thời gian trung bình là 11,73 ngày.

Bảng 5. Tình trạng tái phát sau 3 tháng theo thể lâm sàng

\begin{tabular}{|c|c|c|c|}
\hline $\begin{array}{l}\text { Tái phát } \\
\text { Thể lâm sàng }\end{array}$ & $\begin{array}{c}\text { Có } \\
(\mathrm{SL}, \%)\end{array}$ & $\begin{array}{l}\text { Không } \\
\text { (SL,\%) }\end{array}$ & $\mathbf{p}$ \\
\hline Thể đơn thuân & $\begin{array}{c}4 \\
(18,18 \%)\end{array}$ & $\begin{array}{c}18 \\
(81,82 \%)\end{array}$ & $\begin{array}{c}<0,05 \\
(p=\end{array}$ \\
\hline Thế kết hợp & $7(87,5 \%)$ & $1(12,5 \%)$ & $0,014)$ \\
\hline Chung & $\begin{array}{c}11 \\
(36,67 \%)\end{array}$ & $\begin{array}{c}19 \\
(63,33 \%)\end{array}$ & \\
\hline
\end{tabular}

Nhân xét: Sau 3 tháng điêu trị số bênh nhân tái phát chiếm $36,67 \%$ trong đó các bệnh nhân thể kết hợp $(87,5 \%)$ tỷ lệ tái phát cao hơn hẳn bệnh nhân thể đơn thuân(18,18\%).

\section{BÀN LUÂ̂N}

Đặc điểm chung của đối tượng nghiên cứu. Tuổi mắc bệnh trong nghiên cứu của chúng tôi phần lớn là nhóm tuổi trẻ từ 5-10 tuổi $(63,3 \%)$, tuổi trung bình là $6,1 \pm 2,26$. Nghiên cứu của các tác giả Nguyễn Ngọc Sáng (2016) và Safaei A. A., Maleknejad S. (2010)[3] cũng cho thây tuổi mắc bệnh trung bình là 7,75 $\pm 3,7$ tuổi. Như vậy là tương đương, chủ yếu là tuổi học đường.

Giới tính trong nghiên cứu cho thây tỷ lệ trẻ nam rất cao chiếm $80 \%$ (tỷ lệ nam/nữ: 4/1). Nghiên cứu của các tác giả cũng cho thấy tỷ lệ nam thường cao gấp 2 đến 3 lân trẻ gái. Chủ yếu bệnh nhân sống ở vùng nông thôn (80\%).

Đánh giá kết quả điều trị. Triệu chứng lâm sàng chủ yếu là phù $(100 \%)$, tăng huyết áp $(40 \%)$, thiểu niệu $(26,7 \%)$. Nghiên cứu của nhiêu tác giả như Mallory L. Downie và cộng sự báo cáo năm 2017 [7] cũng có kết quả tương tự, triêu chứng chủ yếu là phù và thiểu niệu, với các mức độ khác nhau, có thể phù to kèm theo cổ trướng, tràn dịch đa màng, có thể dấn đến đau bụng, khó thở, nhiều trường hợp tràn dịch màng tinh hoàn ở trẻ trai. Protein và albumin máu giảm nặng, cholesterol tăng, protein niệu cao. Nghiên cứu của Gipson D. S. (2016)[4] cũ̃ng cho thấy giá trị của xét nghiệm cận lâm sàng là rất quan trọng trong ý nghĩa tiên lượng bệnh và chỉ định điều trị, nhất là protein niệu.

Đáp ứng tốt với corticoid chiếm $76,7 \%$ các trường hợp, với thời gian trung bình là 11,73 ngày. Nghiên cứu của Safaei A. A. (2010) tại Ấn Độ trên 44 trẻ mắc Hội chứng thận hư cho thây đáp ứng tốt với steroid là $79,5 \%$ [3]. Theo Improving Global Outcomes (KDIGO) liệu pháp cho Hội chứng thận hư là corticosteroid đường uống, đáp ứng tốt thuyên giảm $80 \%$ trẻ mắc HCTH. Nghiên cứu của Kaddah A. (2012) [6]trên
100 trẻ mắc HCTH cho thây có $66 \%$ đáp ứng tốt với steroid, $9 \%$ phát triển thành suy thận mạn tính. Nghiên cứu của Mubarak M. (2011) [8] trền 135 trẻ dưới 18 tuổi mắc HCTH ở Pakistan cho thấy tỷ lệ đáp ứng steroid là $65,2 \%$. Tổng hợp nhiều nghiên cứu ngẫu nhiên có đối xứng nhẳm đánh giá tác dụng của steroid trên trẻ mắc $\mathrm{HCTH}$ cho thấy, thuốc được sử dụng chủ yếu là prednisolon, hầu hết các triệu chứng giảm đáng kể trong thời gian 2 tuần, thuyên giảm hoàn toàn đến không tái phát thường phải điều trị kéo dài đến hai năm [5].

Tỷ lệ bệnh nhân tái phát chiếm 36,67\% trong đó chủ yếu là các bệnh nhân HCTHTP kết hợp $(87,5 \%)$.

\section{KẾT LUẬN}

Qua nghiên cứu 30 bệnh nhi nhập viện với bệnh Hội chứng thận hư tiên phát, cho thây phần lớn bệnh nhi là trẻ nam chiếm $80 \%$, tập trung chủ yếu ở lứa tuổi 5-10 tuổi, đặc trưng bởi các triệu chứng lâm sàng là phù $(100 \%)$, tăng huyết áp $(40 \%)$, thiểu niệu $(26,7 \%)$ và cận lâm sàng: Protein niệu 24h trung bình 163,26 $\mathrm{mg} / \mathrm{kg} / 24 \mathrm{~h}$; albumin máu giảm nặng, cholesterol máu tăng. Đáp ứng điều trị với corticosteroid là $76,7 \%$ với thời gian đáp ứng trung bình là 11,73 ngày. Tỷ lệ tái phát sau 3 tháng điêu trị là $36,67 \%$, trong đó chủ yếu là bệnh nhân thể kết hợp (87,5\%).

\section{TÀI LIÊU THAM KHẢO}

1. Bộ, $Y$ và tế (2015), "hướng dẫn chẩn đoán và điểu tri một số bệnh thường gặp ở trẻ em".

2. Nguyển Ngọc Sáng và Lế Nam Trà (2016), "Hội chứng thận hư tiên phát", Sách giáo khoa Nhi khoa, Nhà xuất bản y học, tr. 1150 - 1161 .

3. Safaei L. S. A. A., Maleknejad S. (2010), "Clinical and laboratory findings and therapeutic responses in children with nephrotic syndrome", Indian journal of nephrology. 20(2), tr. 68-71.

4. Debbie S Gipson., et al. (2016), "Complete remission in the nephrotic syndrome study network", Clinical Journal of the American Society of Nephrology. 11(1), tr. 81-89.

5. Deirdre Hahn., et al. (2015), "Corticosteroid therapy for nephrotic syndrome in children", Cochrane database of systematic reviews(3).

6. Ahmed Kaddah., et al. (2012), "Epidemiology of primary nephrotic syndrome in Egyptian children", J Nephrol. 25(05), tr. 732-737.

7. Downie L. M., Gallibois C. Parekh S R., et al (2017), "Nephrotic syndrome in infants and children: pathophysiology and management", Paediatr Int Child Health. 37(4), tr. 248-258.

8. Mubarak, Muhammed., Kazi (2011), "Clinicopathologic characteristics and steroid response of IgM nephropathy in children presenting with idiopathic nephrotic syndrome", Apmis. 119(3), tr. 180-186. 